Petrographic Descriptions of Selected Rock Specimens From the Meade Peak Phosphatic Shale Member, Phosphoria Formation (Permian), Southeastern Idaho
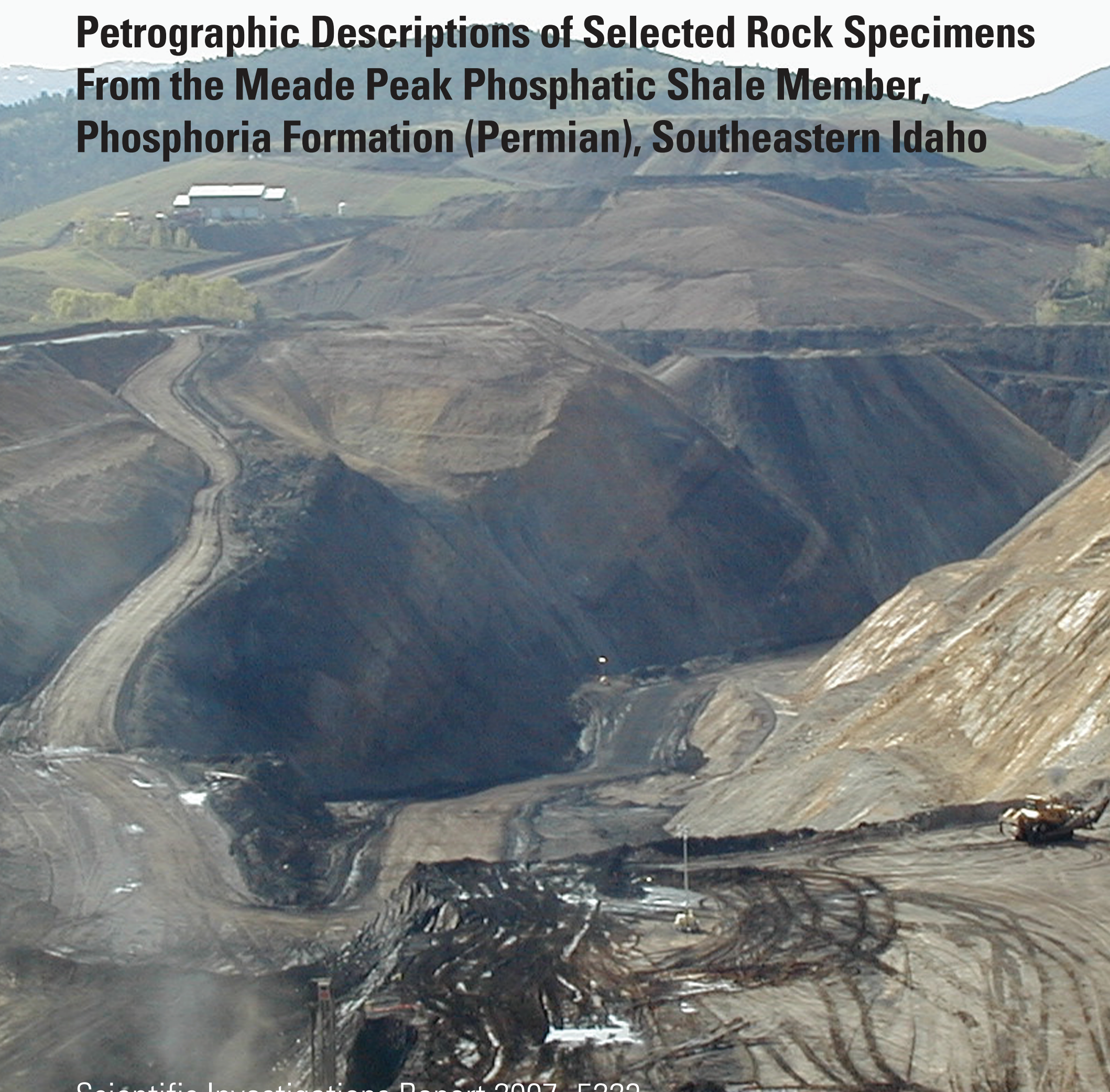

Sciéntific Investigations-Repórt 2007-5223

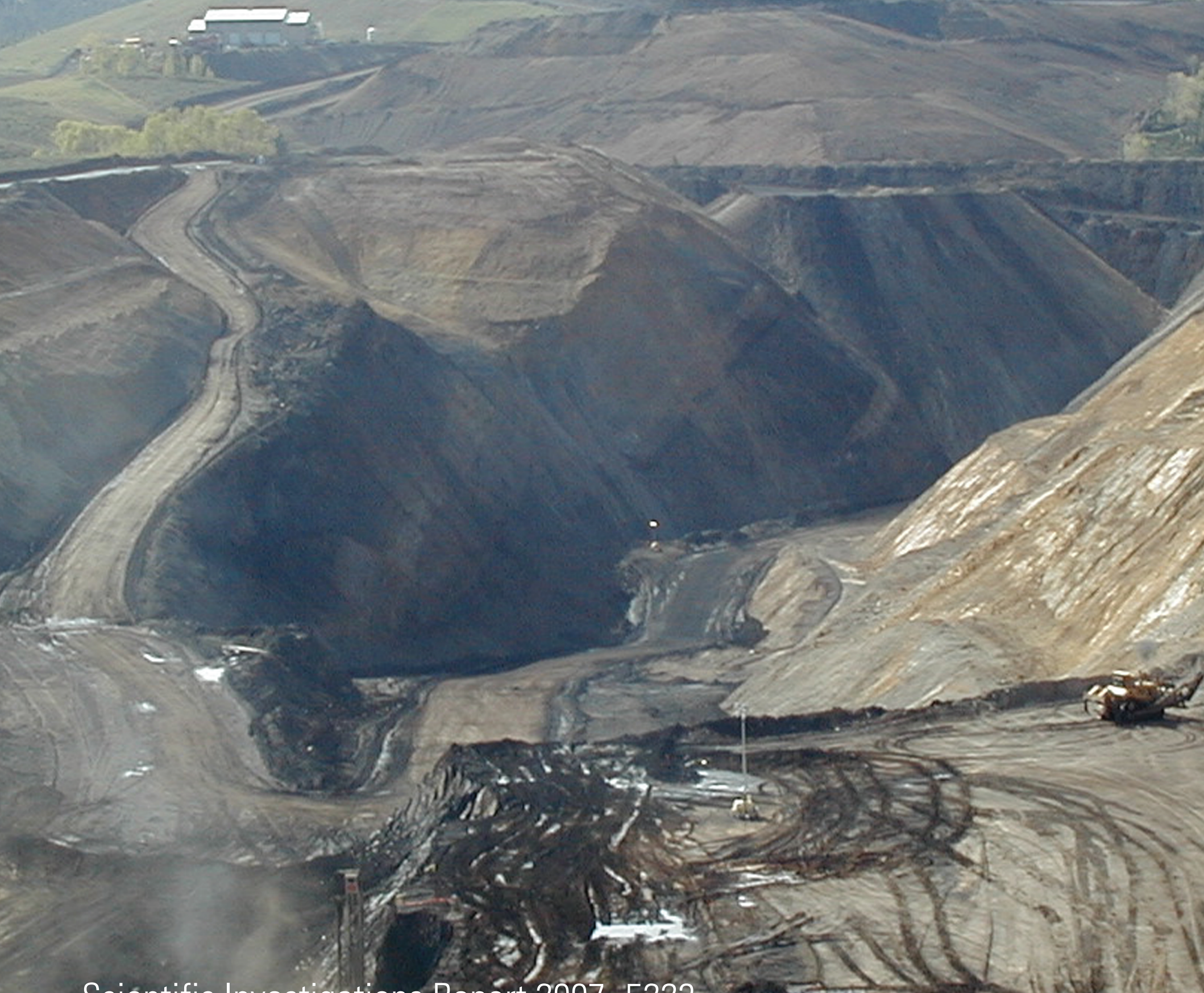

3x-rasis

U.S. Department of the Interior

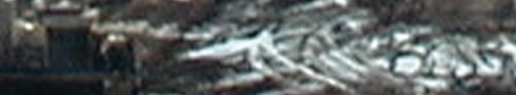

U.S. Geological Survey 
Cover: Rasmussen Ridge mine, Caribou County, Idaho 


\section{Petrographic Descriptions of Selected Rock Specimens From the Meade Peak Phosphatic Shale Member, Phosphoria Formation (Permian), Southeastern Idaho}

By Edward A. Johnson, Richard I. Grauch, and James R. Herring

Scientific Investigations Report 2007-5223 


\section{U.S. Department of the Interior DIRK KEMPTHORNE, Secretary}

\section{U.S. Geological Survey \\ Mark D. Myers, Director}

\section{U.S. Geological Survey, Reston, Virginia: 2007}

For product and ordering information:

World Wide Web: http://www.usgs.gov/pubprod

Telephone: 1-888-ASK-USGS

For more information on the USGS--the Federal source for science about the Earth, its natural and living resources, natural hazards, and the environment:

World Wide Web: http://www.usgs.gov

Telephone: 1-888-ASK-USGS

Any use of trade, product, or firm names is for descriptive purposes only and does not imply endorsement by the U.S. Government.

Although this report is in the public domain, permission must be secured from the individual copyright owners to reproduce any copyrighted materials contained within this report.

Suggested citation:

Johnson, E.A., Grauch, R.I., and Herring, J.R., 2007, Petrographic descriptions of selected rock specimens from the Meade Peak Phosphatic Shale Member, Phosphoria Formation (Permian), southeastern Idaho: U.S. Geological Survey Scientific Investigations Report 2007-5223, 17 p. 


\section{Contents}

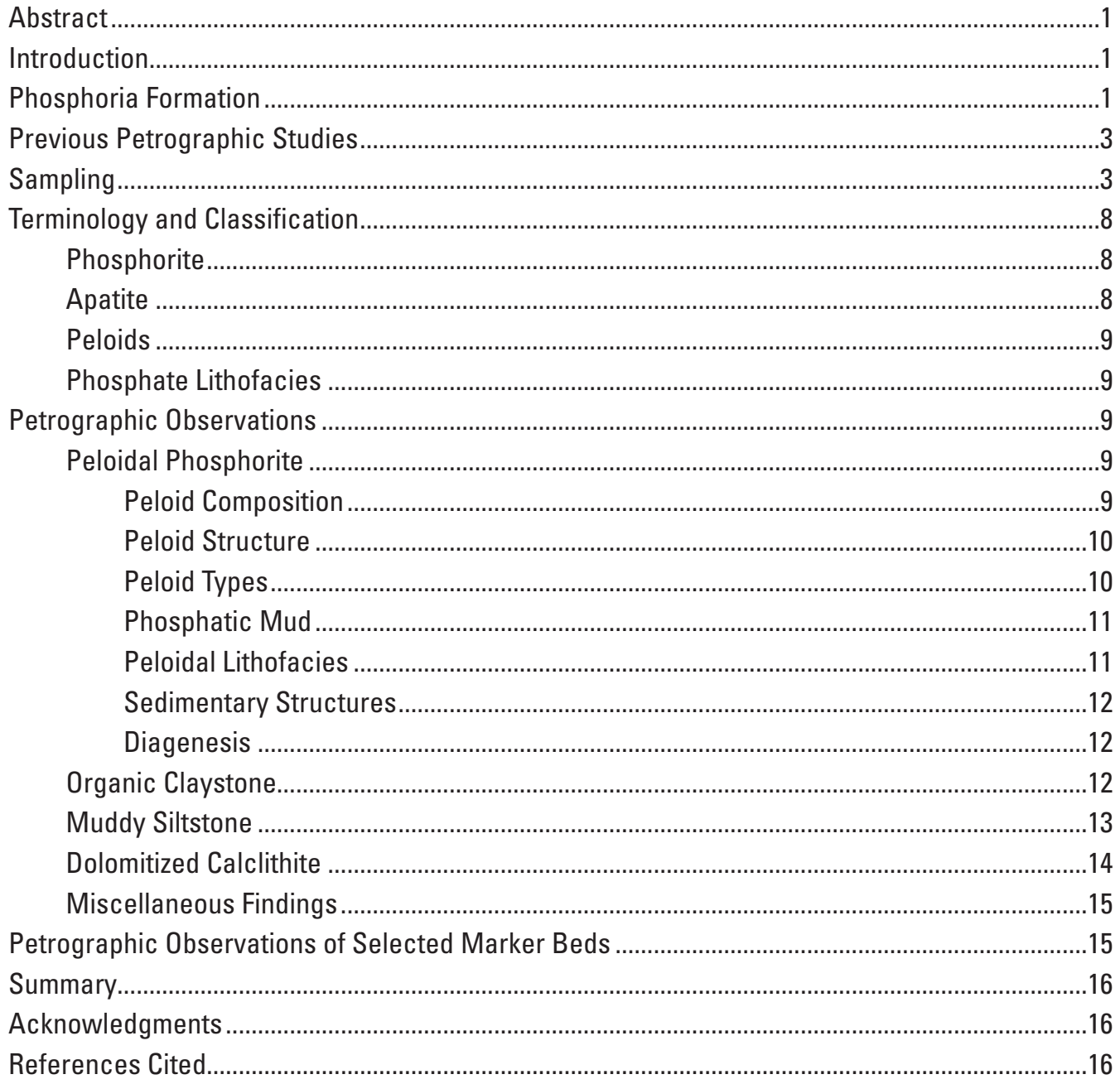

\section{Figures}

1. Map showing locations of phosphate mines and associated measured stratigraphic sections from which specimens were selected for petrographic study

2. Diagram showing average thicknesses of formal and informal members of the Phosphoria Formation and average thicknesses of informal mining zones in the Meade Peak Phosphatic Shale Member

3. Photomicrograph showing opaque peloids in a specimen of silty, organic claystone collected from middle waste zone at Enoch Valley mine 
4. Photomicrograph showing complex peloids in a specimen of grainstone phosphorite collected from upper ore zone ( $D$ bed) at Enoch

Valley mine.

5. Photomicrograph showing translucent peloids in a specimen of phosphatic, dolomitic calclithite collected from lower ore zone (false cap) at

Dry Valley mine

\section{Tables}

1. Lithofacies in the Meade Peak Phosphatic Shale Member as represented by the thin sections used in this study

2. Number of thin sections examined from the five mined zones in the Meade Peak Phosphatic Shale Member in the two stratigraphic sections sampled at each of the four mines studied 


\title{
Petrographic Descriptions of Selected Rock Specimens From the Meade Peak Phosphatic Shale Member, Phosphoria Formation (Permian), Southeastern Idaho
}

\author{
By E.A. Johnson', R.I. Grauch'1, and J.R. Herring'
}

\section{Abstract}

Based on petrographic observations of 135 thin sections, rocks in the Meade Peak Phosphatic Shale Member of the Permian Phosphoria Formation in southeastern Idaho can be placed into one of four major lithofacies: organic claystone, muddy siltstone, peloidal phosphorite, and dolomitized calclithite-in order of decreasing abundance.

Organic claystones are the most common lithofacies in the Meade Peak. Many of these rocks contain sufficient amounts of silt to make silty, organic claystones a common subtype. Organic claystones commonly contain crystals of muscovite and bioclasts as accessory components, and they are typically parallel laminated. Muddy siltstones are composed primarily of quartz silt, but some feldspar and rare carbonate silt are also present; some rocks are parallel laminated. Phosphate peloids are composed of varying amounts of opaque, complex, and translucent material, and observed internal structures are classified as simple, banded, cored, zoned, oolitic, nucleated, and polynucleated. Opaque, complex, and translucent peloids form the framework grains of three peloidal phosphorite rocks: wackestone phosphorite, packstone phosphorite, and grainstone phosphorite. Wackestone phosphorite is phosphatic-mud supported and contains more than 10 percent peloids; it is the most common type of phosphorite. Packstone phosphorite is peloid supported and contains interstitial phosphatic mud; it is also a common type. Grainstone phosphorite is peloid supported but lacks phosphatic mud; it is the least common type. Dolomitized calclithites contain three types of carbonate grains: macrocrystalline, microcrystalline, and crystalline with a microcrystalline nuclei-in order of decreasing abundance. Based on chemical staining and X-ray diffraction analyses, most of the carbonate is dolomite. Sufficient amounts of quartz silt or muddy material allow some rocks to be called silty dolomitized calclithite or muddy dolomitized calclithite, respectively. Sedimentary structures are absent except in some muddy dolomitized calclithites. Organic claystones, muddy siltstones, and dolomitized calclithites are detrital deposits.

\footnotetext{
${ }^{1}$ U.S. Geological Survey, Denver Federal Center, Box 25046, Denver, CO 80225
}

Many rocks in the Meade Peak contain calcite and apatite as fracture fillings and vug linings. As expected, peloidal phosphorites are most common in ore zones, and detrital rocks are most common in waste zones. Mine-specific marker beds are mostly composed of dolomitized calclithite.

\section{Introduction}

As part of the U.S. Geological Survey (USGS) Western United States Phosphate (WUSP) Project-established primarily to study the presence of trace elements, particularly selenium, in the Permian Phosphoria Formation in southeastern Idaho-a subtask was established to describe the petrologic features of rocks collected from the Meade Peak Phosphatic Shale Member (hereafter shortened to Meade Peak). Specimens were selected as splits from several extensive sets of samples collected from a broad study area (fig. 1) for use in various petrologic and geochemical analyses conducted within other tasks and subtasks in the project. In making selections, the objective was to obtain representatives of the major rock types, or lithofacies, present in the Meade Peak. Thin sections cut from 135 rock specimens resulted in 199 individual petrographic descriptions. From these data, it is apparent that four major lithofacies dominate the Meade Peak: organic claystone, muddy siltstone, peloidal phosphorite, and dolomitized calclithite, in decreasing order of apparent abundance.

\section{Phosphoria Formation}

The Lower to Upper Permian (Leonardian through Guadalupian age) Phosphoria Formation (Wardlaw and Collinson, 1986; Wardlaw, 1995) was deposited in the central part of an epicontinental marine embayment on the west margin of the North American craton. This embayment, known as the Sublet Basin (as used by Maughan, 1979), extended over an area of about $100,000 \mathrm{mi}^{2}$, and the Phosphoria sea (as used by Sheldon, 1963) occupied its central part. The Phosphoria Formation is now present in parts of six states: Idaho, Wyoming, 


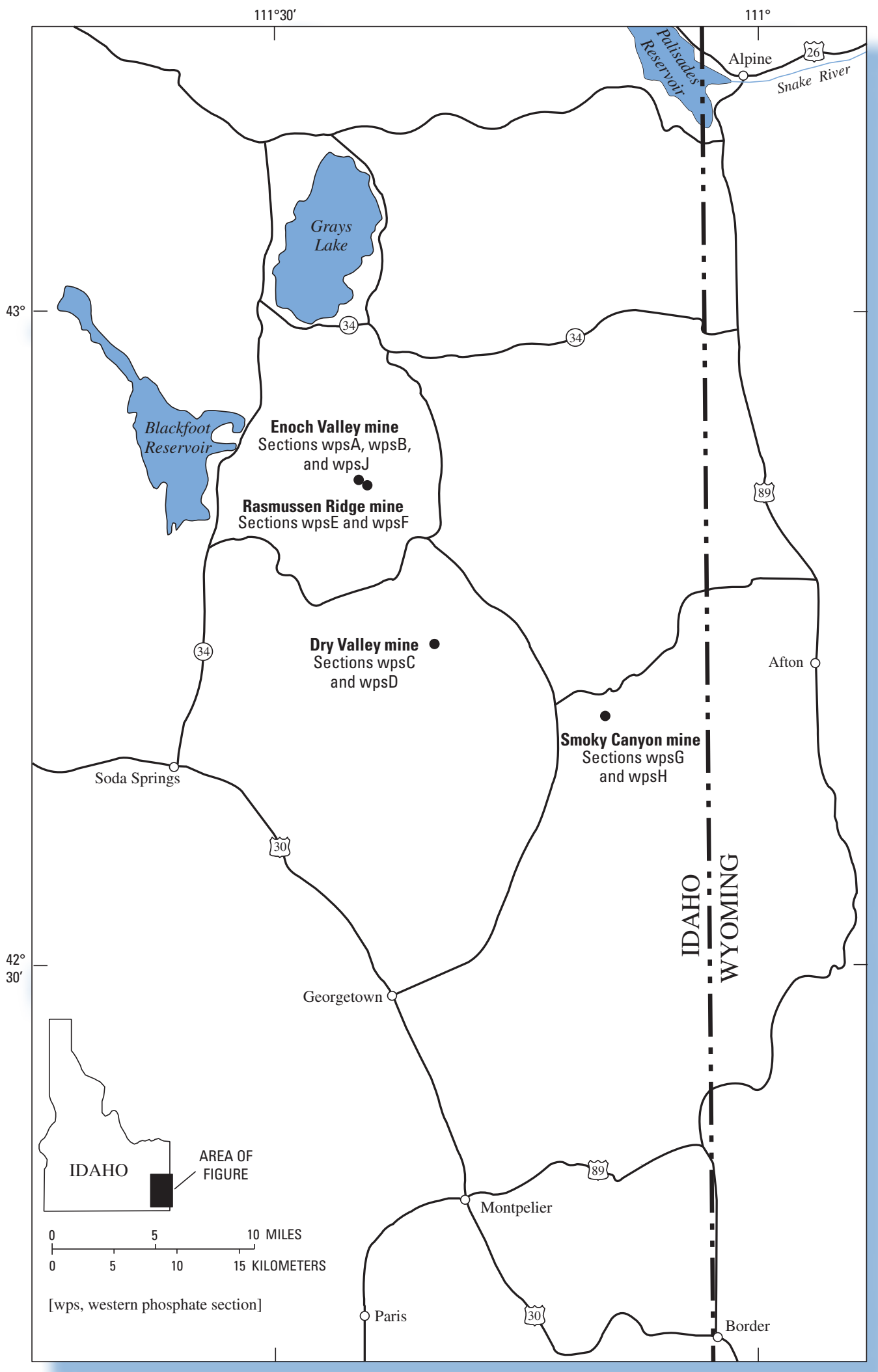

Figure 1. Locations of phosphate mines and associated measured stratigraphic sections in southeastern Idaho, from which specimens were selected for petrographic study. 
Montana, Utah, Nevada, and Colorado—in order of decreasing area.

Richards and Mansfield (1912) first used the term Phosphoria Formation to separate out the upper two members of the previously named Permian Park City Formation (Boutwell, 1907) and designated Phosphoria Gulch, Bear Lake County, Idaho, as the type locality. After many years of confusing modifications to the Permian stratigraphic nomenclature in the region, McKelvey and others (1959) published what became the definitive work on the Park City and Phosphoria Formations, and in the process established (or reconfirmed) six formal or informal members for the Phosphoria. In ascending order, they are: lower chert member, Meade Peak Phosphatic Shale Member, Rex Chert Member, cherty shale member, Retort Phosphatic Shale Member, and Tosi Chert Member (fig. 2A). Within the boundaries of this study, only the Meade Peak, Rex Chert, and cherty shale members are present. In southeastern Idaho, the Meade Peak has been subdivided into five informal zones by the phosphate mining industry. These zones are, in ascending order: lower waste (including the fishscale marker bed at the base), lower ore, middle waste, upper ore, and upper waste (fig. $2 B$ ). In addition, many individual mines have local names that apply to specific marker beds in the zones exposed on their properties. Examples include the B mudstone in the lower ore zone at the Dry Valley mine and the twin limes in the middle waste zone at the Rasmussen Ridge mine.

\section{Previous Petrographic Studies}

Although many reports have been written on the Phosphoria Formation, petrographic studies are few in number, and most of these focus mainly on diagenetic processes. The earliest significant petrographic study is that conducted by Donald Emigh of the Idaho Bureau of Mines and Geology; in the late 1950s, he studied the Phosphoria phosphorites from selected sites in Idaho, Montana, and Utah. As part of this work, Emigh (1958) proposed a broad classification scheme for sedimentary phosphate deposits. He also proposed a nomenclature for phosphate pellets in the Phosphoria, but he did not present a lithologic classification of phosphorites. This work was later summarized, with slight modifications, in a paper published by the Intermountain Association of Geologists (Emigh, 1967). The next significant study was conducted by Curtis Mabie and Hal Hess of the U.S. Bureau of Mines in the early 1960s. Mabie and Hess (1964) studied 21 ore samples collected from the Phosphoria in Idaho, Montana, and Utah. These workers presented their own nomenclature for phosphate pellets and proposed two lithologic classification schemes for phosphorites, one based on mineral composition and the other on metallurgical characteristics, neither of which has been widely accepted. Also in the early 1960s, Dick Sheldon of the USGS conducted an extensive study of the Permian rocks in western Wyoming. As part of this effort, Sheldon (1963) made petrographic observations of phosphorites and carbonate rocks in the Phosphoria. Although Sheldon described his findings, he did not propose a classification scheme for pellets or phosphorites. A following study by Peter Cook, as a Ph.D. dissertation at the University of Colorado, was based on the examination of 100 thin sections cut from specimens of the Meade Peak, specifically the upper ore zone. Cook (1969) applied his own pellet nomenclature but offered no lithologic classification of phosphorites. The most recent work was done by Eric Hiatt, as part of a Ph.D. dissertation at the University of Colorado. Hiatt (1997) does not list a nomenclature for phosphate pellets but does adopt and slightly modify a lithologic classification proposed by Cook and Shergold (1986).

\section{Sampling}

A regional sampling program of the Meade Peak was designed by the WUSP Project to provide rocks for various petrologic and geochemical studies. In order to obtain relatively unweathered samples, collections were made from the pit floors and highwalls of four active phosphate mines. The mines sampled-Enoch Valley, Rasmussen Ridge, Dry Valley, and Smoky Canyon — are all located within several tens of miles north to east of Soda Springs, Idaho (fig. 1). At each mine, two stratigraphic sections were measured and described, a less-weathered section and a more-weathered section, determined by the pre-mining depth of the rocks below the land surface. In addition, one core of the Meade Peak was measured and described. Each of the stratigraphic sections, ranging in thickness from 118 to $215 \mathrm{ft}$, includes most of the Meade Peak; in several cases some of the overlying Rex Chert Member is included and in one case some of the underlying Grandeur Member of the Park City Formation is included. Grab samples were collected from each of the stratigraphic sections, and the number of samples per section ranged from 33 to 87 . Sample selections were made to assure representation of all of the major lithofacies (table 1). It is important to note that no systematic approach was used in this sampling activity. Therefore, only the broadest generalizations can be drawn in regard to the vertical and horizontal distribution of lithofacies. Specimens singled out for thin sectioning were labeled in the field, or in the case of the core, selected out of core boxes at the USGS facility in Lakewood, Colo. The specimens were then shipped to a commercial petrographic company for standard thin sectioning. In addition, several thin sections were stained using sodium cobaltinitrate for potassium feldspar and plagioclase feldspar, and several others were stained using alizarine red for calcite and dolomite. Table 2 tabulates the number of thin sections examined from the five mined zones encountered in the two stratigraphic sections sampled at each of the four mines studied. 

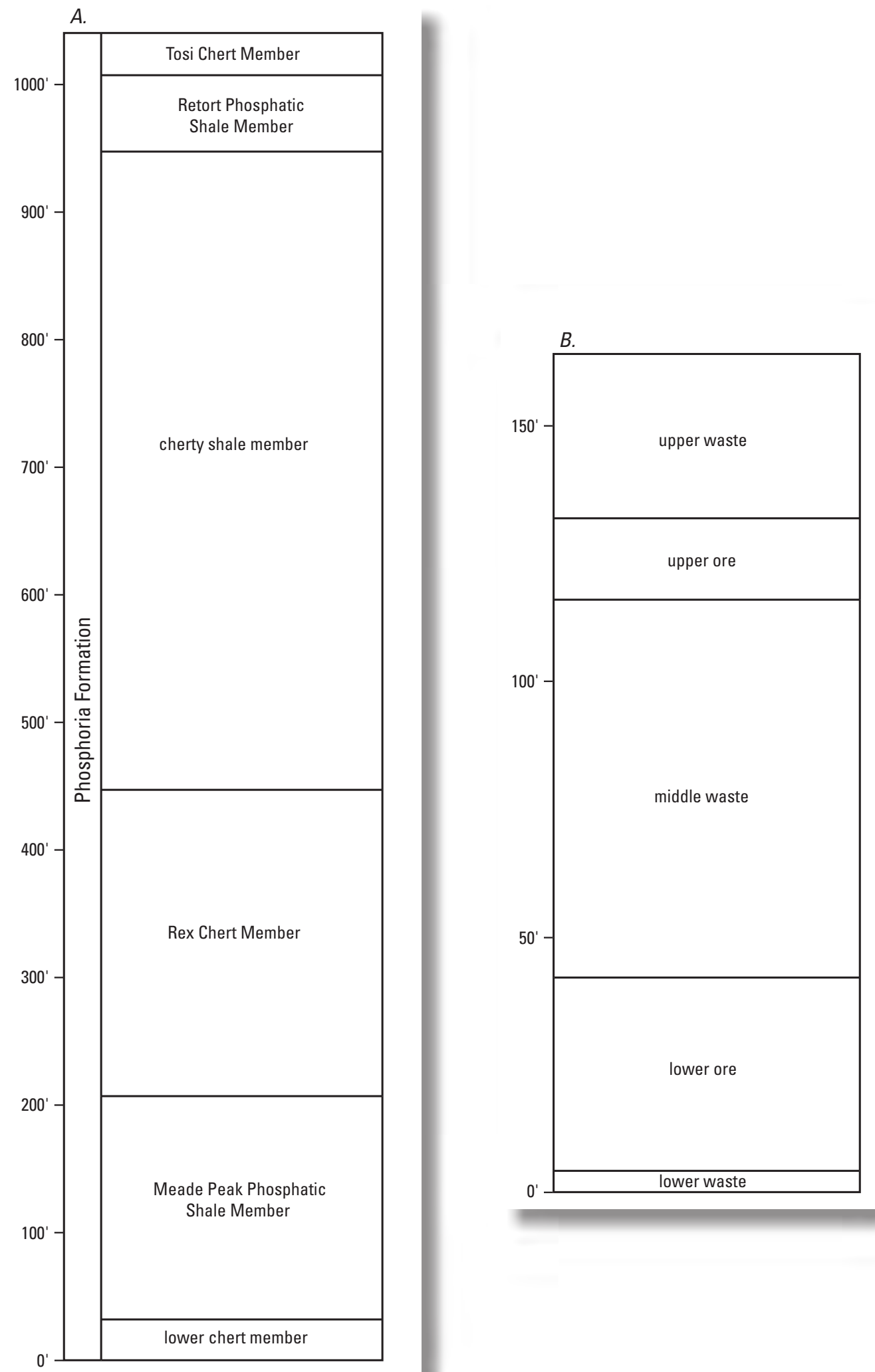

Figure 2. A, Average thicknesses of formal and informal members of the Phosphoria Formation in Western Phosphate Field, southeastern Idaho (McKelvey and others, 1959). B, Average thicknesses of informal zones of the Meade Peak Phosphatic Shale Member as used by phosphate mining industry. Based on stratigraphic sections measured for this study. 
Table 1. Lithofacies in the Meade Peak Phosphatic Shale Member of the Phosphoria Formation, as represented by the thin sections used in this study (for location of sections, see figure 1). Some thin sections are listed in more than one place on the table, a result of several lithofacies being present as individual stratum on one thin section. Details of the stratigraphic sections are in Tysdal and others (1999), Tysdal and others (2000a), Tysdal and others (2000b), Tysdal and others (2000c), and Grauch and others (2001).

[Each thin section has three notations: wps, an abbreviation for western phosphate section; a single capital letter identifying the measured stratigraphic section; and a number indicating the footage above the base of the section. Some sample notations end with a hyphenated letter, which represents a further subdivision, and some notations end with the letter T, which stands for thin section. As an example, wpsA023T is a western phosphate study specimen collected $23 \mathrm{ft}$ above the base of the Meade Peak stratigraphic section A and was intended for thin sectioning. A few footage values listed in the table vary from the others in the placement of zeros, but the intended footage is apparent]

\begin{tabular}{|c|c|c|c|c|c|c|c|}
\hline LITHOFACIES & SECTION A & SECTION B & SECTION C & SECTION D & SECTION E & SECTION G & SECTION J \\
\hline & $\begin{array}{l}\text { Enoch } \\
\text { Valley }\end{array}$ & $\begin{array}{l}\text { Enoch } \\
\text { Valley }\end{array}$ & $\begin{array}{c}\text { Dry } \\
\text { Valley }\end{array}$ & $\begin{array}{c}\text { Dry } \\
\text { Valley }\end{array}$ & $\begin{array}{c}\text { Rasmussen } \\
\text { Ridge }\end{array}$ & $\begin{array}{l}\text { Smoky } \\
\text { Canyon }\end{array}$ & $\begin{array}{l}\text { Enoch } \\
\text { Valley }\end{array}$ \\
\hline Sandy, wackestone phosphorite & & & & wpsD207 & & & \\
\hline Silty, packstone phosphorite & wpsA163T & wpsB026T & & & & & \\
\hline Grainstone phosphorite & & wpsB136T & $\begin{array}{l}\text { wpsC029 } \\
\text { wpsC031 } \\
\text { wpsC032 }\end{array}$ & & & $\begin{array}{l}\text { wpsG010 } \\
\text { wpsG110-E }\end{array}$ & \\
\hline Organic claystone & $\begin{array}{l}\text { wpsA023T } \\
\text { wpsA029T } \\
\text { wpsA118T } \\
\text { wpsA147T }\end{array}$ & $\begin{array}{l}\text { wpsB068T } \\
\text { wpsB073T } \\
\text { wpsB091T } \\
\text { wpsB115T } \\
\text { wpsB131T }\end{array}$ & wpsC155 & $\begin{array}{l}\text { wpsD046 } \\
\text { wpsD049 } \\
\text { wpsD068 } \\
\text { wpsD069 }\end{array}$ & wpsE114 & wpsG038 & $\begin{array}{l}\text { wpsJ49.4 } \\
\text { wpsJ52.2 } \\
\text { wpsJ57.8 } \\
\text { wpsJ61.3 } \\
\text { wpsJ64.8 } \\
\text { wpsJ67.1 } \\
\text { wpsJ67.3 } \\
\text { wpsJ66.8 } \\
\text { wpsJ71.0 } \\
\text { wpsJ72.2 } \\
\text { wpsJ72.9 } \\
\text { wpsJ73.5 } \\
\text { wpsJ106.5 } \\
\text { wpsJ122.5 } \\
\text { wpsJ129.8 } \\
\text { wpsJ130.2 } \\
\text { wpsJ132.5 }\end{array}$ \\
\hline
\end{tabular}


Table 1. Lithofacies in the Meade Peak Phosphatic Shale Member of the Phosphoria Formation, as represented by the thin sections used in this study (for location of sections, see figure 1). Some thin sections are listed in more than one place on the table, a result of several lithofacies being present as individual stratum on one thin section.-Continued

\begin{tabular}{|c|c|c|c|c|c|c|c|}
\hline LITHOFACIES & SECTION A & SECTION B & SECTION C & SECTION D & SECTION E & SECTION G & SECTION J \\
\hline & $\begin{array}{l}\text { Enoch } \\
\text { Valley }\end{array}$ & $\begin{array}{l}\text { Enoch } \\
\text { Valley }\end{array}$ & $\begin{array}{c}\text { Dry } \\
\text { Valley }\end{array}$ & $\begin{array}{c}\text { Dry } \\
\text { Valley }\end{array}$ & $\begin{array}{c}\text { Rasmussen } \\
\text { Ridge }\end{array}$ & $\begin{array}{l}\text { Smoky } \\
\text { Canyon }\end{array}$ & $\begin{array}{l}\text { Enoch } \\
\text { Valley }\end{array}$ \\
\hline \multirow[t]{3}{*}{ Silty, organic claystone } & wpsA023T & wpsB046T & wpsC153 & wpsD036 & wpsE065 & & wpsJ49.4 \\
\hline & wpsA029T & wpsB062T & & wpsD046 & wpsE067 & & wpsJ51.1 \\
\hline & wpsA078T & wpsB073T & & wpsD049 & wpsE073 & & wpsJ52.2 \\
\hline \multirow[t]{11}{*}{ Silty, organic claystone (cont.) } & wpsA118T & wpsB078T & & & wpsE108 & & wpsJ58.3 \\
\hline & wpsA122T & wpsB099T & & & & & wpsJ61.3 \\
\hline & wpsA127T & wpsB115T & & & & & wpsJ64.8 \\
\hline & wpsA147T & wpsB125T & & & & & wpsJ71.0 \\
\hline & & wpsB129T & & & & & wpsJ72.9 \\
\hline & & wpsB148T & & & & & wpsJ73.6 \\
\hline & & wpsB157T & & & & & wpsJ122.5 \\
\hline & & & & & & & wpsJ130.2 \\
\hline & & & & & & & wpsJ131.9 \\
\hline & & & & & & & wpsJ132.5 \\
\hline & & & & & & & wpsJ163.7 \\
\hline \multirow[t]{4}{*}{ Phosphatic, organic claystone } & & & wpsC075 & & wpsE073 & & wpsJ131.9 \\
\hline & & & wpsC090 & & wpsE082 & & \\
\hline & & & wpsC112 & & & & \\
\hline & & & wpsC130 & & & & \\
\hline \multirow[t]{11}{*}{ Muddy siltstone } & wpsA153T & & wpsC153 & wpsD068 & wpsE065 & & wpsJ52.2 \\
\hline & & & & wpsD069 & wpsE073 & & wpsJ57.8 \\
\hline & & & & wpsD071 & wpsE075 & & wpsJ67.3 \\
\hline & & & & wpsD207 & wpsE76.5 & & wpsJ72.2 \\
\hline & & & & & wpsE086 & & wpsJ73.5 \\
\hline & & & & & wpsE090 & & wpsJ106.5 \\
\hline & & & & & wpsE093 & & wpsJ128.6 \\
\hline & & & & & & & wpsJ129.8 \\
\hline & & & & & & & wpsJ136.8 \\
\hline & & & & & & & wpsJ165.9 \\
\hline & & & & & & & wpsJ176.9 \\
\hline \multirow[t]{4}{*}{ Sandy, muddy siltstone } & wpsA163T & & & & & & wpsJ73.6 \\
\hline & & & & & & & wpsJ165.9 \\
\hline & & & & & & & wpsJ176.9 \\
\hline & & & & & & & wpsJ181.7 \\
\hline \multirow[t]{2}{*}{ Phosphatic, muddy siltstone } & & & wpsC075 & wpsD199 & wpsE093 & & \\
\hline & & & wpsC150 & wpsD06 & & & \\
\hline
\end{tabular}


Table 1. Lithofacies in the Meade Peak Phosphatic Shale Member of the Phosphoria Formation, as represented by the thin sections used in this study (for location of sections, see figure 1). Some thin sections are listed in more than one place on the table, a result of several lithofacies being present as individual stratum on one thin section.-Continued

\begin{tabular}{|c|c|c|c|c|c|c|c|}
\hline LITHOFACIES & SECTION A & SECTION B & SECTION C & SECTION D & SECTION E & SECTION G & SECTION J \\
\hline & $\begin{array}{l}\text { Enoch } \\
\text { Valley }\end{array}$ & $\begin{array}{l}\text { Enoch } \\
\text { Valley }\end{array}$ & $\begin{array}{c}\text { Dry } \\
\text { Valley }\end{array}$ & $\begin{array}{l}\text { Dry } \\
\text { Valley }\end{array}$ & $\begin{array}{c}\text { Rasmussen } \\
\text { Ridge }\end{array}$ & $\begin{array}{l}\text { Smoky } \\
\text { Canyon }\end{array}$ & $\begin{array}{l}\text { Enoch } \\
\text { Valley }\end{array}$ \\
\hline \multirow[t]{2}{*}{ Dolomitic calclithite } & & wpsB003T & & wpsD017 & & & wpsJ58.3 \\
\hline & & wpsB038T & & wpsD025 & & & wpsJ66.8 \\
\hline \multirow[t]{5}{*}{ Dolomitic calclithite (cont.) } & & wpsB065T & & wpsD033 & & & wpsJ67.1 \\
\hline & & wpsB121T & & wpsD121 & & & wpsJ79.2 \\
\hline & & & & wpsD201 & & & wpsJ85.9 \\
\hline & & & & & & & wpsJ92.3 \\
\hline & & & & & & & wpsJ97.6 \\
\hline \multirow[t]{7}{*}{ Muddy, dolomitic calclithite } & & wpsB068T & & wpsD058 & wpsE087 & wpsG046-B & wpsJ 2.5 \\
\hline & & & & wpsD062 & wpsE122 & & wpsJ49.4 \\
\hline & & & & wpsD069 & & & wpsJ52.4 \\
\hline & & & & & & & wpsJ54.8 \\
\hline & & & & & & & wpsJ58.3 \\
\hline & & & & & & & wpsJ63.6 \\
\hline & & & & & & & wpsJ72.9 \\
\hline Silty, dolomitic calclithite & & & wpsC096 & & & wpsG093 & \\
\hline \multirow[t]{2}{*}{ Phosphatic, dolomitic calclithite } & & & & wpsD017 & & wpsG014 & \\
\hline & & & & wpsD031 & & wpsG106 & \\
\hline Sandstone & & & wpsC146 & & & & \\
\hline
\end{tabular}


Table 2. Tabulations of the number of thin sections examined from the five mined zones in the Meade Peak Phosphatic Shale Member of the Phosphoria Formation, encountered in the two stratigraphic sections sampled at each of the four mines studied in this report (for location of sections, see figure 1).

\begin{tabular}{|c|c|c|c|c|c|c|c|}
\hline \multicolumn{8}{|c|}{ Measured Sections } \\
\hline \multirow[t]{2}{*}{$\begin{array}{c}\text { Unit } \\
\text { sampled }\end{array}$} & \multicolumn{3}{|c|}{ Enoch Valley } & \multicolumn{2}{|c|}{ Dry Valley } & \multirow{2}{*}{$\begin{array}{c}\text { Rasmussen } \\
\text { Ridge }^{4}\end{array}$} & \multirow{2}{*}{$\begin{array}{c}\text { Smoky } \\
\text { Canyon }^{4} \\
\text { wps } \\
\text { G }^{2}\end{array}$} \\
\hline & $\begin{array}{c}\text { wps } \\
A^{1}\end{array}$ & $\begin{array}{c}\text { wps } \\
B^{2}\end{array}$ & $\begin{array}{c}\text { wps } \\
\mathbf{J}^{3}\end{array}$ & $\begin{array}{c}\text { wps } \\
\text { C }^{1}\end{array}$ & $\begin{array}{c}\text { wps } \\
D^{2}\end{array}$ & & \\
\hline Upper waste & 1 & 2 & 3 & 4 & 3 & 4 & 0 \\
\hline Upper ore & 5 & 4 & 1 & 1 & 1 & 1 & 6 \\
\hline Middle waste & 5 & 11 & 30 & 5 & 9 & 10 & 3 \\
\hline Lower ore & 2 & 6 & 1 & 5 & 5 & 0 & 3 \\
\hline Lower waste & 1 & 2 & 1 & 0 & 0 & 0 & 0 \\
\hline \multicolumn{8}{|c|}{${ }^{1}$ More-weathered sample } \\
\hline \multicolumn{8}{|c|}{${ }^{2}$ Less-weathered sample } \\
\hline${ }^{3}$ Core & & & & & & & \\
\hline
\end{tabular}

\section{Terminology and Classification}

\section{Phosphorite}

Defining the word phosphorite is problematic. According to the Glossary of Geology (Jackson, 1997), phosphorite is a sedimentary rock with a high enough content of phosphate minerals to be of economic interest. Many workers consider this definition too general and would prefer a more quantitative version. Suggestions as to the minimum amount of phosphate required for a rock to be termed a phosphorite has been set as low as 5 percent $\mathrm{P}_{2} \mathrm{O}_{5}$ (Slansky, 1986), but minimum values of 19 percent (Cressman and Swanson, 1964) or 20 percent (Boggs, 1987) are most commonly cited. However, adding such a requirement to the definition can cause problems in two ways. First, using a $\mathrm{P}_{2} \mathrm{O}_{5}$ percentage in the definition requires a chemical analysis to legitimately classify a rock as a phosphorite, and this procedure takes time and is costly. Second, a set $\mathrm{P}_{2} \mathrm{O}_{5}$ minimum would most likely exclude some Florida deposits that are economical at values as low 10 percent $\mathrm{P}_{2} \mathrm{O}_{5}$ in the bulk rock. But those deposits are an exception-most mined phosphorites in the U.S. contain at least 20 percent $\mathrm{P}_{2} \mathrm{O}_{5}$.

As proposed by Slansky (1979), and as adopted by Cook and Shergold (1986) and Trappe (2001), a value of 18 percent $\mathrm{P}_{2} \mathrm{O}_{5}$ equates to about 50 percent phosphate components by visual inspection. Using Slansky's definitions, rocks with greater than 50 percent phosphate components are termed phosphorite and rocks with less than 50 percent phosphate components are termed phosphate rock. However, Slansky stated that the actual $\mathrm{P}_{2} \mathrm{O}_{5}$ percentage can range from 10 to 22 , depending on the types of phosphate components. Although less than perfect, this scheme provides a quick hand-specimen method that more or less matches an anticipated analytical result. Slansky's (1979) scheme does not solve the problem of phosphatic mud in peloidal rocks, which can contain a substantial amount of $\mathrm{P}_{2} \mathrm{O}_{5}$. The scheme also does not solve the problem of phosphatic argillaceous rocks that show few megascopic grains in hand specimens but can contain a substantial amount of $\mathrm{P}_{2} \mathrm{O}_{5}$.

\section{Apatite}

Apatite group minerals are complex in their composition—general formula $\mathrm{Ca}_{5}\left(\mathrm{PO}_{4}, \mathrm{CO}_{3}\right)_{3}(\mathrm{~F}, \mathrm{OH}, \mathrm{CL})$ - and can be present in either igneous, metamorphic, or sedimentary rocks. The word collophane was used for many years as the finegrained apatite group present in marine phosphates. However, collophane is not a distinct mineral but a mixture of varying components, and in this way use of this term is analogous to use of the term limonite to describe various iron oxide/hydroxide compounds. Gulbrandsen (1960) reported that the apatite group mineral in the Meade Peak is intermediate among francolite, dehrnite, wilkeite, and ellestadite in composition, and suggested calling it carbonate fluorapatite instead of collophane. The substitution of carbonate $\left(\mathrm{CO}_{3}\right)$ for phosphate $\left(\mathrm{PO}_{4}\right)$ is a principal characteristic of marine apatite, thus the descriptive compositional name. The term carbonate fluorapatite has since been widely accepted as the marine apatite in the Phosphoria. However, carbonate fluorapatite is shortened to simply apatite in this report. The material that was interpreted as apatite during this petrographic study is an integral component of peloidal phosphorites, and it is ubiquitous within peloids and as part of the phosphatic mud. It is light amber 
to black in plane light and typically black (pseudoisotropic) under crossed nicols because of the aggregate polarizing effect resulting from its cryptocrystalline character. A more microcrystalline character in slightly coarser specimens can cause the apatite to appear weakly birefringent as the microscope stage is rotated.

\section{Peloids}

Traditionally, the round particles observed in phosphorites have been referred to as pellets, but a more definitive word is needed. The standard dictionary definition of pellet is too general to be of use in describing phosphorite components, and the Glossary of Geology (Jackson, 1997) restricts its usage to a structureless, homogeneous component of carbonate rock, such as a fecal pellet. Some workers have adapted the term phosphate allochems to describe the coarser components in phosphorites, and this general term is acceptable. The word phosphate links the term directly to phosphorites (as opposed to carbonates) and the word allochem is a collective term that includes rounded and non-rounded particles such as pellets, ooliths, fossils (and their fragments), and intraclasts. However, to be more specific, the term phosphate peloids (also spelled pelloids) is used in this report to describe the rounded, phosphatic aggregates that constitute the majority of particles in phosphorites. In doing so, the definition of peloid in the Glossary of Geology has been modified here by restricting the type of particles that can be included in the term. Again, the word phosphate links the term directly to phosphorites. In this report, the term phosphate peloid has been shortened to simply peloid (peloidal in adjective form).

\section{Phosphate Lithofacies}

The only concerted attempts at an original classification of phosphorites in the Phosphoria are the two schemes proposed by Mabie and Hess (1964) — one based on mineral composition and the other based on metallurgical characteristics. The first of the two schemes was designed to categorize ore by grade, and the second was designed for use in the ore beneficiation process. Neither of these two schemes, however, has applicability to this study. Instead, this study uses a classification scheme based on the original textural classification of carbonate rocks by Dunham (1962) as later modified by Cook and Shergold (1986) for suitability with phosphorites. This scheme is also the basic classification scheme used by Hiatt (1997) in his petrographic study of Phosphoria phosphorites. An important feature of this classification scheme is that it can be used with either hand specimens or thin sections. To Cook and Shergold's scheme, two minor modifications are added for this study: (1) the word peloid is substituted for grain (as originally used by Dunham, 1962) because, in the case of phosphorites, peloids usually far outnumber any bioclasts, lithoclasts, or fragments of minerals that might be present; and (2) the word phosphatic is used as an adjective for mud (as originally used by Dunham, 1962) to more closely define the type of mud. Accordingly, the resulting classification adopted for this study, although not intended to replace the classification used by Cook and Shergold (1986), is as follows:

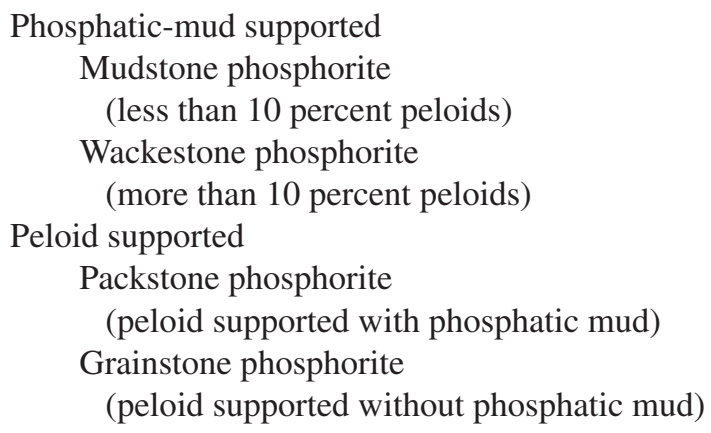

\section{Petrographic Observations}

Only four major lithofacies were observed during this petrographic study of the Meade Peak: organic claystone, muddy siltstone, peloidal phosphorite, and dolomitized calclithite. Because the specimens from which the thin sections were cut were not collected systematically, the order of relative abundance of these four lithofacies is unknown; however, field observations indicate that this listing might be in the decreasing order of abundance. This ranking is for the entire Meade Peak, but relative abundance of lithofacies varies by mining zone; for example, ore zones contain more peloidal phosphorite than waste zones. In the following sections of this report, peloidal phosphorite is discussed first because of its obvious economic importance; following that, the other lithofacies are discussed in their perceived order of decreasing relative abundance.

\section{Peloidal Phosphorite}

\section{Peloid Composition}

Peloids are the major framework constituents of peloidal phosphorites. Peloids appear as featureless particles in hand specimens, but when viewed in thin sections with a polarizing microscope they are complex and varied. In hand specimens, peloids are seen to be spherical or ovoid in shape and seem to range in size from medium grained to very coarse grained (Wentworth, 1922). However, under the microscope the shape and size of the peloids are a function of the orientation of a particular peloid to the plane of the thin section. For example, an ovoid peloid can appear spherical if cut normal to its long axis, and a coarse-grained peloid can appear finer grained if not cut at its maximum diameter. Because of this, the reporting of shapes or of ranges in diameters would be misleading, so shapes are not described and only maximum diameters are cited. From petrographic observations, it is apparent that peloids are made up of varying amounts of three basic materials: 
Opaque material.-This peloidal component is the most common. It appears more or less homogeneous when viewed under a microscope, is very dark brown or black in plane light, and is totally opaque in polarized light. It is probably composed of some mixture of organic matter and cryptocrystalline phosphate mineral, possibly apatite.

Complex material.- This peloidal component is also common. It appears heterogeneous when viewed under a microscope, is typically some shade of light to dark brown or orange brown in plane light, and is dark brown to black in polarized light. It is probably composed of various forms of phosphate mineral, possibly apatite with or without some amount of organic matter.

Translucent material. - This peloidal component is rare. It appears more or less homogeneous when viewed under a microscope, and is bright brown or bright yellow in plane light and black in polarized light.

\section{Peloid Structure}

Also from petrographic observations, the internal structures of peloids can be placed into one of eight categories:

Simple.-Commonly, peloids lack any noticeable internal structure.

Banded.-This term is applied when the outer perimeter of a peloid displays one (single) or several (multiple) concentric bands of peloidal material differing from that of the main body of the peloid.

Cored.-Many peloids display a central core composed of a peloidal material differing from that of the main body. As defined here, these internal spherical masses must have a diameter less than half the diameter of the whole peloid.

Zoned.-This structure, which is uncommon, describes a peloid when its main body displays several concentric zones of differing material.

Oolitic.- Rarely, a peloid will be so tightly zoned that it appears oolitic in form. Such peloids are probably not true ooliths; that is, the structure is most likely diagenetic in origin rather than a recording of the primary outward growth of a peloid from a central nucleus.

Nucleated. - In rare cases, a peloid will contain a single nucleus that differs significantly in composition from normal peloidal material (for example, a particle of quartz or a fossil fragment). By convention, the diameter of the nucleus must be less than half the diameter of the peloid.

Polynucleated.-Even rarer, a peloid will contain two or more nuclei, and in these cases the combined nuclei can be of any diameter.

Composited.-Some rare peloids show an encasement of two or more individual peloids within a single body.

\section{Peloid Types}

A review of the pellet nomenclature of Emigh (1958) and Mabie and Hess (1964), as used in their respective petrographic studies of the Phosphoria, led to the conclusion that neither set of terms was wholly applicable to this study. Consequently, a simple peloid nomenclature was developed using the three basic materials that compose peloids. In almost all cases, the peloid name is accompanied by a structural modifier (for example, banded).

Opaque peloids. - Simple opaque peloids (fig. 3) are the most common type observed in thin sections. Many opaque peloids show some inclusions of quartz or carbonate silt, as well as small patches of translucent amber-colored material that is probably cryptocrystalline phosphate mineral. Opaque peloids with a single band of translucent material are common. A few opaque peloids were observed to show single bands of complex material, and opaque peloids in one thin

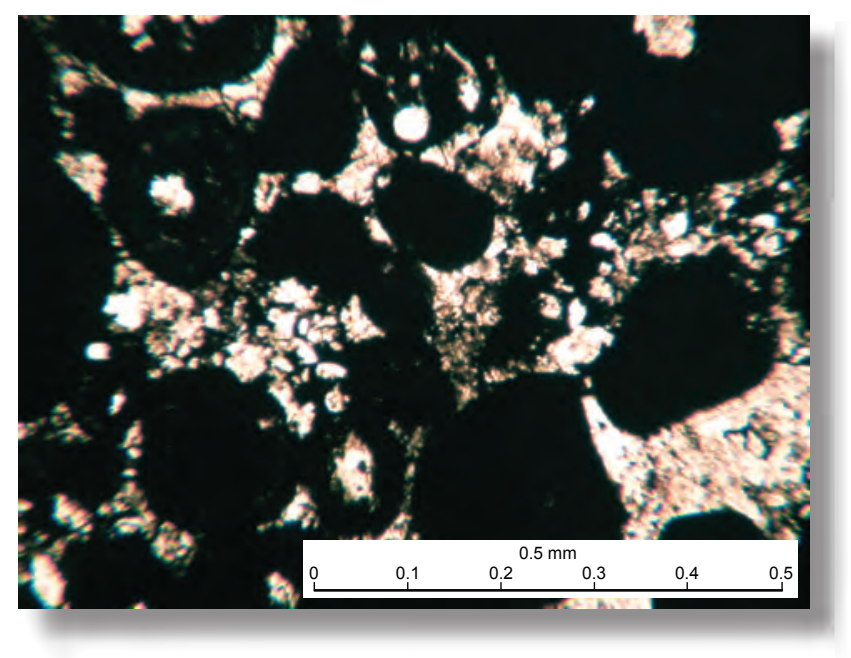

Figure 3. Photomicrograph showing a patch of opaque peloids in a specimen of silty, organic claystone (wpsJ131.9) collected from middle waste zone at Enoch Valley mine (for explanation of specimen notation, see table 1). This view in plane light shows black opaque peloids separated by white carbonate material. White patches within some peloids are quartz silt.

section display a single band of randomly orientated, siltsized carbonate minerals. Rare opaque peloids are cored with complex material.

Because opaque peloids are dark in color and commonly ovoid in shape, it is tempting to assume that they are fecal in origin. McKelvey and others (1953) argued against such an origin for any pellets in the Phosphoria by pointing out that the pellets (1) have a wide range in size, (2) are well sorted within individual beds, (3) conform to regional trends in average size, (4) commonly have a compound nature, and (5) are oolitic and even pisolitic in some cases. If one considers the first point - the wide range in size - it seems possible that different size invertebrates would have produced different size fecal pellets. In regard to points two and three-good sorting within individual beds and regional trends in sorting - both of 
these phenomena could possibly be explained by low-energy currents moving along the sea floor. Concerning points four and five - the compound nature of some pellets and the fact that some are oolitic or pisolitic-it is possible that most of these features are a function of diagenesis. Thus, a fecal origin for some opaque peloids cannot be excluded, an opinion generally shared by Emigh (1958), Cook (1969), and Tucker (1981).

Complex peloids. - Complex peloids (fig. 4) are the most interesting and probably provide the best evidence for diagenesis in peloidal phosphorites. Most complex peloids are simple - that is, they lack any organized internal structure. However, many complex peloids display a single band of less complex material or translucent material. Rare complex peloids show a single band of opaque material, and even rarer complex peloids are cored with opaque material. Some complex peloids contain a few silt-sized, angular fragments of quartz and carbonate. Zoned and oolitic structures were rarely observed, but where noted they are associated with complex peloids.

Translucent peloids. - Translucent peloids (fig. 5) are relatively uncommon, but are easily spotted by their bright color and clear appearance at first glance; however, most are cloudy to some degree when examined closely. Simple translucent

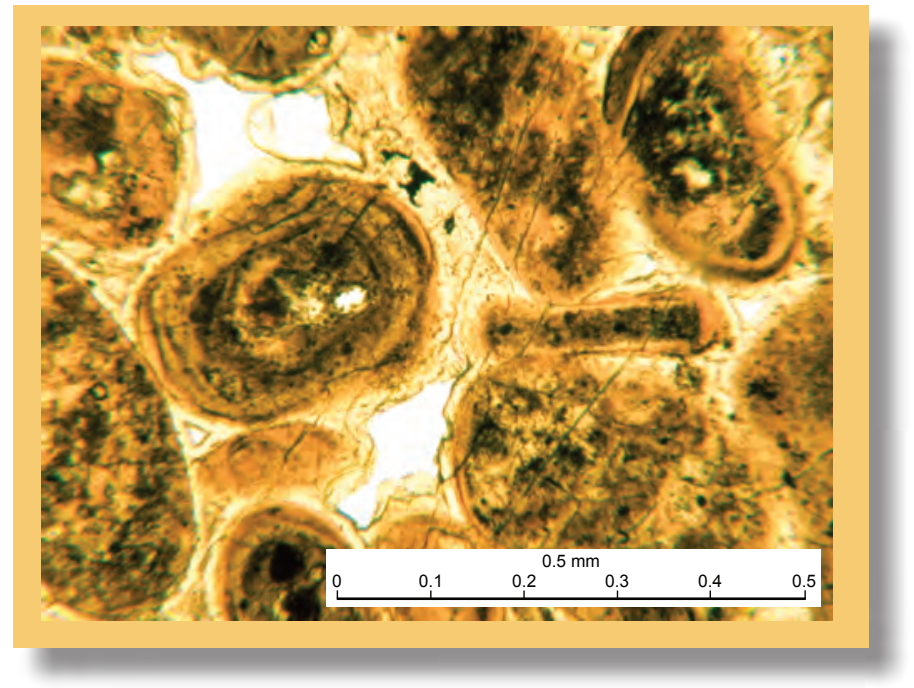

Figure 4. Photomicrograph showing complex peloids in a specimen of grainstone phosphorite (wpsB136T) collected from upper ore zone ( $D$ bed) at Enoch Valley mine. This view in plane light shows brown, simple (structureless), banded, and zoned complex peloids separated by light-brown, discontinuous areas of siliceous material. White, angular patches are holes in thin section.

peloids are the most common type, but many are cored with opaque peloidal material, indicating a transitional relation; some rare peloids are cored with complex peloidal material. Rare translucent peloids display a single band of opaque peloidal material or a single band of complex peloidal material.

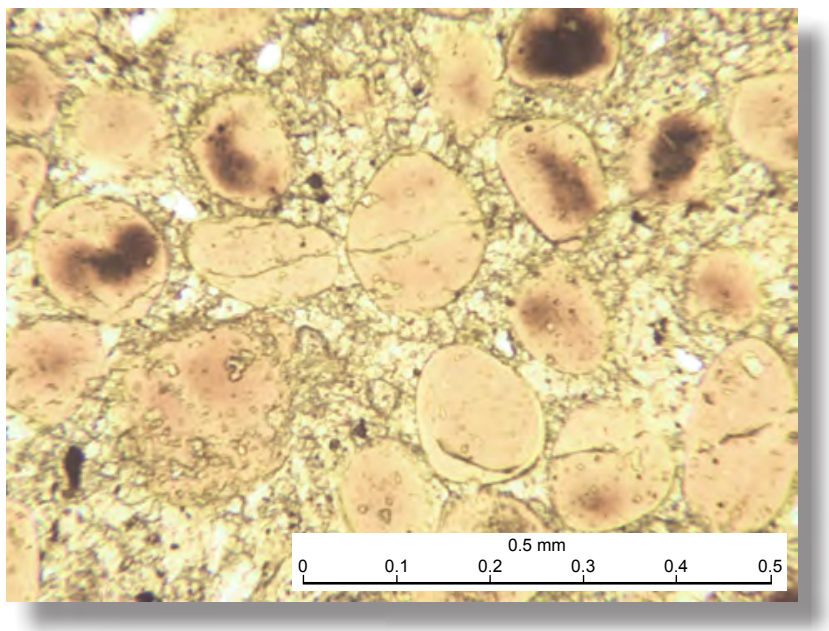

Figure 5. Photomicrograph showing translucent peloids in a specimen of phosphatic, dolomitic calclithite (wpsD031) collected from lower ore zone (false cap) at Dry Valley mine. This view in plane light shows lightorange, translucent peloids separated by light-yellow, carbonate material. Dark brown patches within some peloids are opaque peloid material possibly being altered to translucent material.

\section{Phosphatic Mud}

The term phosphatic mud is defined here as the interstitial material separating individual peloids. Emigh (1967) referred to this material as cementing matrix [sic] because it forms the binding agent that holds the framework grains in position to form a rock. Under the microscope, phosphatic mud is typically some shade of dark brown in plane light and black in polarizing light. Because of its dark color, phosphatic mud is probably composed predominately of organic-rich clay. However, on the edges of the thin sections where the rock slice was less than $30 \mu \mathrm{m}$ thick, phosphatic mud was observed to be complex, and it undoubtedly contains varying amounts of phosphatic mineral. In many cases, phosphatic mud contains a variety of silt-sized particles such as quartz and feldspar fragments, carbonate lithoclasts, mica crystals, and bioclasts. Silt-sized peloids are also common in the phosphatic mud. What is usually thought of as mineral cement was not readily apparent in the thin sections but is undoubtedly present in small amounts in the form of recrystalized phosphate mineral, calcite, and in special cases, silica.

\section{Peloidal Lithofacies}

Three types of peloidal phosphorite were observed: (1) wackestone phosphorite, (2) packstone phosphorite, and (3) grainstone phosphorite-in order of decreasing amounts of phosphatic mud. Most of the thin sections of peloidal phosphorite show only one of the three lithofacies, but many also show several lithofacies as individual stratum. Each thin 
section showing these lithofacies contains a unique array of peloid types, peloid structures, and phosphatic mud and its components, making the thin sections almost kaleidoscopic in their variations. Many of these rocks contain silt, but this study required the presence of at least 20 percent of these grains before attaching the word silty as a modifier. For the rare sandy rocks, a minimum value of 20 percent was also required before attaching the word sandy.

Wackestone phosphorite.-Wackestone phosphorite was a commonly observed peloidal rock. Several mediumand coarse-grained peloids were observed in thin sections of these rocks, but all other peloids were either very fine or fine grained. Thus, the average maximum peloid size might be classed as fine grained. Almost half of the thin sections contain sufficient amounts of silt to warrant the term silty wackestone phosphorite. Quartz is by far the most common silt fragment, but some feldspar and carbonate fragments are also present. In addition, one specimen was observed to contain enough sand to warrant the term sandy wackestone phosphorite, and in this case the sand grains are all quartz. The maximum sand size observed was very fine grained. The common presence of silt (and sand) is probably related to the higher phosphatic mud content of these rocks as compared to packstone phosphorites and grainstone phosphorites. Wackestone phosphorites and silty wackestone phosphorites were collected from both the ore zones and the waste zones.

Packstone phosphorite.-Packstone phosphorite was another commonly observed peloidal rock. Several coarsegrained and very coarse grained peloids are represented in thin sections of these rocks, but all others are either very fine, fine, or medium grained. Thus, the average maximum peloid size might be medium grained. Only a few of the thin sections contain sufficient amounts of silt to warrant the term silty packstone phosphorite. Packstone phosphorites were collected from both the ore zones and the waste zones. The fish-scale marker bed (Yochelson, 1968) at the base of the lower waste zone is unlike any other in the Meade Peak. Two specimens of this unit from the Enoch Valley mine are silica-cemented, packstone phosphorites composed of complex and translucent peloids. The complex peloids are almost always banded with complex material darker than that of the peloid, and translucent peloids and lithoclasts are also banded with complex material. Nucleated and polynucleated peloids are common. In addition to the peloids, lithoclasts of quartz and quartzite are common grains. Both medium- and coarse-grained peloids and lithoclasts are present, making coarse the possible average maximum grain size.

Grainstone phosphorite.-Grainstone phosphorite was an uncommonly observed peloidal phosphorite. Although some medium-grained peloids are present, most are either very fine or fine grained. Thus, the average maximum peloid size might be fine grained. None of the thin sections contain sufficient amounts of silt to include silty in the rock name. The scarcity of detrital silt is probably a function of the lower phosphatic mud content of these rocks as compared to packstone phosphorites and wackestone phosphorites. All of the grainstone phosphorites were collected from ore zones.

\section{Sedimentary Structures}

Observing sedimentary structures under the microscope, even with the lowest power objective, is difficult because most features are larger than the view seen through the eyepiece. However, by placing the thin sections on a light table and scanning them with a hand lens, sedimentary structures can be identified. Many of the peloidal phosphorites observed using this method are planar, parallel laminated, albeit weakly in some cases, and a few specimens display wavy, parallel laminations (as defined by Reineck and Singh, 1975). In hand specimens of peloidal phosphorites, the thickness of individual lamina is seen to range from very thin to very thick (as defined by Reineck and Singh, 1975). However, under the microscope, the thickness of lamina is a function of the orientation of the stratification to the plane of the thin section. Because of this, reporting lamina thickness would be misleading.

\section{Diagenesis}

The diagenetic history of the various lithofacies in the Meade Peak is beyond the scope of this study. However, a brief mention of diagenesis as it affects the appearance of peloids is important. Based on the work of Emigh (1958) and Cook (1969), the vast array of peloid views seen through the microscope is mostly a function of the amount and arrangement of organic matter. In general, as diagenesis proceeds, the original content of organic matter gradually mobilizes and is either rearranged within the peloid or is selectively removed from the peloid. As the organic matter migrates outward, the peloid becomes a lighter overall color and one or more darker shells form on the circumference. If a significant amount of the organic matter leaves the peloid, one or more lighter-colored shells will remain around a relatively darker-colored core. In special cases, peloids become zoned or even develop oolitic structure as organic matter segregates as concentric shells within the main body of the peloid. This change in color tone is probably enhanced by the introduction of secondary phosphate mineral that fills the spaces left by the migrating organic matter. The fact that organic matter can freely move toward the edge of the peloid and beyond, and that phosphate-mineralrich solutions can enter the peloid, indicate that what appears to be a dense, solid material is in reality a porous body. It is possible that most peloids were originally structureless bodies with only subtle differences in composition. With time, diagenetic processes acted on these differences giving each peloid, or group of peloids, a unique appearance.

\section{Organic Claystone}

Organic-rich claystones (hereafter called organic claystones) are black in hand specimens and show only a few 
discernable grains when viewed with a hand lens. Under the microscope, they appear almost totally black in both plane and polarized light. The term claystone, as defined by the Glossary of Geology (Jackson, 1997), is a sedimentary rock with greater than 67 percent clay-sized minerals, and the modifying term organic is added here because of the rock's ubiquitous black color. Microscopic observations made in reflected light reveal that the organic matter is primarily solid bitumen (M.J. Pawlewicz, oral commun., 2002). Thin section observations disclosed that much of the organic matter is present within densely packed, opaque peloids. Because more than one-half of the organic claystones are peloidal, this characteristic is probably the rule rather than the exception. Several mediumand coarse-grained organic peloids were observed, but all others were either very fine or fine grained. Thus, the average maximum peloid size might be fine grained. On the edges of some thin sections, where the rock slice is relatively thin, complex patterns in various shades of amber are visible in plane light. This feature indicates that some organic claystones are in fact a mixture of organic matter and phosphate mineral that is present as phosphatic mud or as a component of the opaque peloids. In some of these cases the name phosphatic organic claystone might be more appropriate. This combination of organic matter and phosphate mineral might place some of these rocks in the category of mudstone phosphorites (phosphatic-mud supported with less than 10 percent peloids) as defined by Cook and Shergold (1986).

Almost all of the organic claystones contain accessory components. The most common of these is silt-sized quartz, with lesser amounts of feldspar. In more than one-half of the rocks, silt-sized material exceeds 20 percent and the modifying term silty was applied. Some organic claystones contain phosphate peloids, but rarely in excess of 20 percent. Also present in some organic claystones are crystals of muscovite aligned parallel to lamination. Perhaps the most interesting accessory components of some organic claystones are siltsized bioclasts. Based on observations by R.R. Charpentier (oral commun., 2002), the most common bioclasts are forams (in both polar and equatorial views), brachiopod shell fragments (including some with pseudopuncate shell structure), and sponge spicules. In addition, C.A. Sandberg (oral commun., 2002) recognized fragments of fish teeth.

As viewed on a light table, almost all organic claystones are parallel laminated. Planar parallel lamination is the most common type, but discontinuous planar parallel laminations and wavy parallel laminations were also noted (as defined by Reineck and Singh, 1980). Graded bedding was seen in some thin sections, and, where observed in orientated specimens, inverse grading was found to be more common than normal grading. Rare examples of soft-sediment deformation and cutand-fill structures were also present.

Organic claystone is present throughout the Meade Peak. However, as might be expected, these rocks are most common in the waste zones, particularly in the middle waste zone.

Four samples of organic claystone were arbitrarily selected for organic geochemistry and vitrinite reflectance
$\left(\mathrm{R}_{\mathrm{o}}\right)$ analysis in an effort to acquire a cursory impression of the Meade Peak's past potential as a source rock for petroleum. Two of the samples were from a measured stratigraphic section at the Smoky Canyon mine (one from the lower ore zone and one from the upper ore zone), and two of the samples were from a core drilled at the Enoch Valley mine (one from the lower ore zone and one from the upper ore zone). The samples were analyzed by M.J. Pawlewicz (written commun., 2001) at the USGS organic geochemistry laboratory in Denver, Colo. Vitrinite reflectance, an indicator of thermal maturity, was measured on solid bitumens from two of the samples- the other two samples did not contain enough organic matter to be measured. The values obtained were 1.41 percent and 1.88 percent, both numbers indicating that the rocks have passed through the oil window and are overmature in regard to oil. Thermal maximum (Tmax), another indicator of thermal maturity, was measured on three of the samples - the fourth sample yielded no results. The values obtained were $449^{\circ} \mathrm{C}, 451^{\circ} \mathrm{C}$, and $563^{\circ} \mathrm{C}$. The higher of the three numbers indicates that the rock has passed through the oil window and is overmature, but the lower numbers indicate that the rock is still within the oil window. Total organic carbon (TOC) was measured on all four of the samples, with values of 2.33 percent, 2.72 percent, 8.85 percent, and 11.08 percent. Although this diminutive sampling of the geochemical properties of the organic claystones has no statistical merit, it does imply that these rocks were good source rocks for petroleum generation.

\section{Muddy Siltstone}

Organic-rich siltstones (hereafter informally called muddy siltstones) are black in hand specimens and show many discernable grains when viewed with a hand lens. Under the microscope, in both plane and polarized light, siltsized fragments appear bright against an almost totally black background. The term siltstone, as defined by the Glossary of Geology (Jackson, 1997), is a sedimentary rock with greater than 67 percent silt-sized material; here, the modifying term muddy is added because organic-rich mud always exceeded 20 percent of the rock. The framework grains are subrounded to subangular, with quartz and feldspar being the most abundant. Some rocks contain small portions of organic-claystone peloids and rarely phosphate peloids; the average maximum size of these constituents might be fine grained.

The quartz grains are clearly recognizable by standard optical properties such as a colorless appearence in plane light and a white or first-order gray appearance in polarized light, the display of undulatory extinction, and the absence of cleavage. Based on these characteristics, quartz dominates the framework grains in the siltstones. The feldspar grains are also colorless in plane light and white or first-order gray in polarized light, but they lack undulatory extinction and their outer margins are commonly transected cleavage planes. Two thin sections of muddy siltstone were stained for potassium feldspar and plagioclase feldspar. In both thin sections the yellow coloration indicative of potassium feldspar was noted on 
some grains. However, despite the rare observation of grains displaying albite twinning in other thin sections of muddy siltstone, the pink coloration indicative of plagioclase feldspar is absent in both of these thin sections. Powder X-ray diffraction (XRD) analyses by Knudsen and others (2002), using Rietveld quantification software for siltstones collected from the wpsJ core, indicated the presence of three types of feldspar: albite, buddingtonite, and orthoclase (for explanation of specimen notation, see table 1). In these samples, any one of the three feldspars could dominate, but commonly buddingtonite is the most abundant and orthoclase the least abundant. Knudsen and others (2002) also identified the presence of relatively small amounts of dolomite and calcite, and probably small amounts of these minerals are present among the framework grains.

Some muddy siltstones contain very fine grained sand as streaks or patches in the rock. In rare cases, this size fraction exceeds 20 percent and the name sandy muddy siltstone is applicable. (One specimen of very fine grained sandstone was also noted during this study.)

Although the intergranular material in the muddy siltstones is composed primarily of black organic-rich mud, this material in most rocks contains common grains of various siliceous minerals at the lower end of the range of silt sizes, with quartz and feldspar predominating. In addition, fragments of muscovite crystals are present in some of this material, as are rare bioclasts similar to those present in some organic claystones. The intergranular material in some muddy siltstones contains amber-colored material that is probably phosphate mineral. In rare cases where this component exceeds 20 percent (at the expense of the organic-rich mud), the name phosphatic siltstone is appropriate, especially if phosphate peloids are also present in the same rock.

All of the framework grains observed in the muddy siltstones are most likely detrital fragments that were deposited in the depositional site as the distal part of a subaqueous, siliciclastic sedimentary wedge. If so, then the prevalent silt size resulted from the natural sorting that took place as the wedge entered deeper water and wave and current energy was reduced. Alternatively, Carroll and others (1998) suggest that the silt fragments settled into the depositional site after being blown into the vicinity by prevailing winds.

Many muddy siltstones are planar parallel laminated, and one example of inverse graded bedding was observed. As might be expected, muddy siltstones are most commonly associated with waste zones, and the phosphatic siltstones are most commonly associated with ore zones.

\section{Dolomitized Calclithite}

Carbonate rocks in the Meade Peak are dark or medium gray to medium brown in hand specimens. They are commonly aphanitic when viewed with a hand lens, but very fine grains are visible in a few specimens. The rocks are well indurated and generally emit a fetid odor when struck with a rock hammer. Outcrop debris are blocky to chip-like. Many specimens display intersecting, light-colored, calcite veinlets.
Rare specimens are parallel laminated and others are fossiliferous. Some of these rocks are readily susceptible to weathering, and where it has taken place the rocks are an ochre color and are altered to a punky, clay-like material.

As viewed under the microscope, the dolomitized calclithites consist of light-colored, silt-sized grains separated from each other by varying amounts of dark-colored intergranular material. The grains are of two types: carbonate and quartz (though probably there are some feldspars as well). In plane light the carbonate grains appear complex and varied. They are typically colorless and cloudy, and rhombic cleavage is commonly observed. In polarized light the carbonate grains show high birefringence and appear pearl gray to pale pastel. The carbonate grains can generally be placed into one of three broad categories, listed in order of decreasing abundance: (1) partially rectangular or trapezoidal, single- or multiple-crystalline units; (2) poorly rounded, microcrystalline masses; or (3) crystalline units with faint, microcrystalline nuclei. Some of these rocks contain all three grain types, but most have only two types, and in rare cases, just one. The poorly rounded, microcrystalline masses (category 2) are interpreted as detrital fragments, and it is postulated that the single- or multiple-crystalline units (category 1) are the result of selective recrystallization of the detrital fragments, probably following deposition. Those crystalline units with microcrystalline nuclei (category 3 ) would then represent a transitional phase in this process. A detrital interpretation, if correct, would eliminate the necessity of conceiving a scheme to explain the unique and transient chemical environment needed for primary carbonates to be precipitated in the middle of the Phosphoria sea. The established environment for the Meade Peak would remain one of phosphate-mineral precipitation (peloidal phosphorites), with intermittent influxes of detrital clay-sized material (organic claystones) and silt (muddy siltstones); the carbonate rocks would then represent just another type of detrital influx. Two conceivable process-source scenarios for the detrital carbonate are speculated: (1) debris flows extending seaward from carbonate reefs marginal to the Phosphoria sea that are now lithified as the Permian Park City Formation, or (2) stream loads consisting of eroded carbonate originally precipitated in sabkhas in what is now central Wyoming and now lithified as the Permian-Triassic Goose Egg Formation. Either possibility could have been facilitated by eustatic falls in sea level.

The term calclithite, as generally defined by the Glossary of Geology (Jackson, 1997), is a fragmental carbonate rock consisting of more than 50 percent extraclasts derived from the erosion of older lithified carbonates. All of the rocks referred to as calclithite in this report contain at least 50 percent carbonate grains, but some rare specimens also contain quartz silt in excess of 20 percent; for these rocks, the modifying term silty is applied.

Differentiating between calcite and dolomite under the microscope is generally difficult, so two thin sections (wpsB003T and wpsJ97.6) were stained with Alizarian Red-S. Almost all of the carbonate grains in the stained thin sections are a subtle beige color that is typically associated 
with dolomite. Red coloration associated with stained calcite is present as veinlet material and in the interiors of some bioclasts. All of this calcite is undoubtedly the result of secondary mineralization. However, red coloration is also present as minute, irregular patches within grains and amidst intergranular material, but whether this calcite is primary or secondary is questionable. Knudsen and others (2002) conducted powder $\mathrm{X}$-ray diffraction analyses on samples labeled as dolostones (their terminology) collected from the wps J core. For those samples that qualified as carbonate rock, about 67 percent of the total rock is dolomite and about 16 percent is calcite.

How dolomite became the dominate carbonate in the calclithites is indeterminable. The detrital grains could have arrived at the depositional site as a mixture of primary calcite (from eroded reef complexes) and primary dolomite (from sabkha supersaline carbonate flats) and remained so. More likely, they could have arrived solely as calcite grains and later selectively dolomitized. If dolomitization did take place, the timing of this process is also indeterminable - did it take place at the same time as the carbonate recrystallization or later?

The intergranular material in the dolomitized calclithites is similar to that contained in the muddy siltstones, being composed primarily of black organic-rich mud with dispersed grains of carbonate, quartz, and feldspar, all at the lower end of the range of silt sizes. In addition, bioclasts are present in some of this material. More than one-half of the dolomitized calclithites contain 20 percent or more organic-rich mud, so the name muddy, dolomitized calclithite is applied to these rocks. For those containing phosphate peloids in excess of 20 percent, which are uncommon, the termed phosphatic, dolomitized calclithites is applied.

Sedimentary structures are generally absent from the dolomitized calclithites. However, these structures seem to increase with an increase in intergranular material. Planar parallel laminations are common in muddy dolomitized calclithites, and graded bedding (both normal and inverse) was observed in some of these rocks.

Dolomitized calclithites and muddy dolomitized calclithites are present in all of the mining subdivisions of the Meade Peak, but as expected, they are particularly common in the waste zones. However, some of the thicker units of these rocks are present in ore zones, and because they are somewhat unique in these zones, they are named and used as local marker beds at some mines. All of the phosphatic, dolomitized calclithites came from ore zones, as would be expected.

\section{Miscellaneous Findings}

Two types of authigenic minerals were observed in thin sections, and both are present as fracture fillings and vug linings. The more common of the two is calcite, and the less common is a translucent-orange phosphate mineral. Because all of the specimens observed were included in subsets of either less-weathered or more-weathered pairs collected at specific mines, it was expected that a petrographic distinction would be apparent between these two degrees of weathering.
Although there are undoubtedly subtle variations between the two categories, no striking differences were noted. However, if certain paired subsets of less-weathered and more-weathered thin sections were viewed on a light table, the less-weathered thin sections tended to have an overall gray tone, whereas the more-weathered thin sections had an overall brown tone. This contrast in color is at least partly the result of differing oxidation history, but the specific components involved were not determined.

\section{Petrographic Observations of Selected Marker Beds}

When observing the Meade Peak in the highwalls of phosphate mines, it can be difficult to pick out the various mining zones because everything appears black. However, personnel at specific mines faced with this problem typically utilize mine-specific marker beds, which in themselves can be difficult to pick out. In some cases, marker beds used at one mine are laterally discontinuous and do not extend beyond the mine property, so they cannot be correlated with marker beds at adjacent mines. In other cases, such as the twin limes in the middle waste at the Rasmussen Ridge and Dry Valley mines, correlation is tempting.

Specimens from several of these marker beds were collected during the course of field work, and a brief discussion of the result of thin section observations follow. A pair of marker beds is present in the middle waste zone at the Rasmussen Ridge and Dry Valley mines, referred to by mine personnel as the twin limes. Personnel at the Rasmussen Ridge mine identified these beds in the highwall while stratigraphic section wpsE was being measured (Tysdal and others, 2000b). Based on thin sections, the lower bed is a silty organic claystone and the upper bed consists of a wackestone phosphorite and a muddy siltstone.

A marker bed at the Enoch Valley mine termed the false cap by mine personnel is present in the lower ore zone (Tysdal and others, 1999). A thin section of this bed collected from wpsA shows the rock to be a dolomitized calclithite.

Three marker beds are recognized by mine personnel in the lower ore zone at the Dry Valley mine. In ascending order, they are: A cap, B mudstone, and false cap (Tysdal and others, 2000a). A thin section of a specimen of the A cap in wpsD contains two lithofacies: dolomitized calclithite and phosphatic, dolomitized calclithite. A thin section of the B mudstone in wpsD shows the rock to be a dolomitized calclithite. The relation, if any, between the false cap at the Dry Valley mine and the false cap at the Enoch Valley mine was not determined. A thin section of the false cap in wpsC shows the rock to be a wackestone phosphorite. Two thin sections were cut from specimens of the false cap in wpsD. One shows the rocks to be a phosphatic, dolomitized calclithite, and the other shows the rock to be a dolomitized calclithite. 
The cap rock is a term used by mine personnel at the Smoky Canyon mine to designate a marker bed in the lower ore zone (Tysdal and others, 2000c). A thin section cut from a specimen collected from the unit in wpsG shows the rock to be a phosphatic, dolomitized calclithite. Another thin section cut from a specimen of the unit in wpsG contains two lithofacies identified as muddy siltstone and silty, wackestone phosphorite.

\section{Summary}

1. The Meade Peak Phosphatic Shale Member of the Permian Phosphoria Formation in southeastern Idaho contains four major lithofacies: organic claystone, muddy siltstone, peloidal phosphorite, and dolomitized calclithite-in order of decreasing abundance.

2. Phosphate peloids are composed of varying amounts of opaque, complex, and translucent material.

3. The internal structures of peloids are classified as simple, banded, cored, zoned, oolitic, nucleated, polynucleated, or composited.

4. Peloidal phosphorites are placed in one of three categories: wackestone phosphorite, packstone phosphorite, or grainstone phosphorite.

5. Wackestone phosphorites are phosphatic-mud supported and contain more than 10 percent peloids, packstone phosphorites contain phosphatic mud but are peloid supported, and grainstone phosphorites are peloid supported and lack phosphatic mud.

6. Organic claystone is the most common lithofacies in the Meade Peak and commonly contains quartz silt, muscovite, and bioclasts as accessory components; it generally is parallel laminated.

7. Muddy siltstone is composed primarily of quartz silt; parallel laminations are common.

8. Dolomitized calclithite contains three types of carbonate grains: macrocrystalline, microcrystalline, and crystalline with microcrystalline nuclei-in order of decreasing abundance. Sedimentary structures are generally absent.

9. Secondary calcite and apatite, observed as fracture fillings and vug linings, are common in all rock types.

10. Peloidal phosphorites are most common in the ore zones, and detrital rocks - organic claystones, muddy siltstones, and dolomitized calclithites - are most common in the waste zones.

11. Mine-specific marker beds are most commonly dolomitized calclithites.

\section{Acknowledgments}

Several USGS geologists provided guidance during this study. Among them are Ron Charpentier and Charlie Sandberg with micropaleontology, Joe Hatch with carbonate deposition, and Mark Pawlewicz with organic geochemistry.

\section{References Cited}

Boggs, Sam, Jr., 1987, Principles of sedimentology and stratigraphy: Columbus, Ohio, Merrill Publishing Company, 784 p.

Boutwell, J.M., 1907, Stratigraphy and structure of the Park City mining district, Utah: Journal of Geology, v. 15, no. 5, p. 434-458.

Carroll, A.R., Stephens, N.P., Hendrix, M.S., and Glenn, C.R., 1998, Eolian-derived siltstone in the Upper Permian Phosphoria Formation- Implications for marine upwelling: Geological Society of America, Geology, v. 26, no. 11, p. 1023-1026.

Cook, P.J., 1969, The petrology and geochemistry of the Meade Peak Member of the Phosphoria Formation: Boulder, Colo., University of Colorado, Ph.D. dissertation, 204 p.

Cook, P.J., and Shergold, J.H., 1986, Proterozic and Cambrian phosphorites-An introduction, in Cook, P.J., and Shergold, J.H., eds., Phosphate deposits of the world, volume 1, Proterozoic and Cambrian phosphorites: Cambridge, England, Cambridge University Press, p. 1-8.

Cressman, E.R., and Swanson, R.W., 1964, Stratigraphy and petrology of the Permian rocks of southwestern Montana: U.S. Geological Survey Professional Paper 313-C, p. 275-569.

Dunham, R.J., 1962, Classification of carbonate rocks according to depositional texture, in Ham, W.E., ed., Classification of carbonate rocks-A symposium: American Association of Petroleum Geologists Memoir 1, p. 108-121.

Emigh, G.D., 1958, Petrography, mineralogy, and origin of phosphate pellets in the Phosphoria Formation: Idaho Bureau of Mines and Geology, Pamphlet 114, 60 p.

Emigh, G.D., 1967, Petrology and origin of phosphorites, in Hale, L.A., ed., Anatomy of the western phosphate field. Fifteenth annual field conference: Salt Lake City, Utah, Intermountain Association of Geologists, p. 103-114.

Grauch, R.I., Tysdal, R.G., Johnson, E.A., Herring, J.R., and Desborough, G.A., 2001, Stratigraphic section and selected semiquantitative chemistry, Meade Peak Phosphatic Shale Member of Permian Phosphoria Formation, central part of Rasmussen Ridge, Caribou County, Idaho: U.S. Geological Survey Open-File Report 99-20-E, 1 sheet. 
Gulbrandsen, R.A., 1960, Petrology of the Meade Peak Phosphatic Shale Member of the Phosphoria Formation at Coal Canyon, Wyoming-A method of X-ray analysis for determining the ratio of calcite to dolomite in mineral mixtures: U.S. Geological Survey Bulletin 1111-C, D, p. 98-105.

Hiatt, E.E., 1997, A paleoceanographic model for oceanic upwelling in a late Paleozoic epicontinental sea-A chemostratigraphic analysis of the Permian Phosphoria Formation: Boulder, Colo., University of Colorado, Ph.D. dissertation, $294 \mathrm{p}$.

Jackson, J.A., ed., 1997, Glossary of geology, fourth edition: Alexandria, Va., American Geological Institute, 769 p.

Knudsen, A.C., Gunter, M.E., Herring, J.R., and Grauch, R.I., 2002, Mineralogical characterization of strata of the Meade Peak Phosphatic Shale Member of the Permian Phosphoria Formation-Channel and individual rock samples of measured section $\mathrm{J}$ and their relationship to measured sections A and B, central part of Rasmussen Ridge, Caribou County, Idaho: U.S. Geological Survey Open-File Report 02-125, $46 \mathrm{p}$.

Mabie, C.P., and Hess, H.D., 1964, Petrographic study and classification of western phosphate: U.S. Bureau of Mines Report of Investigations 6468, 95 p.

Maughan, E.K., 1979, Petroleum source rock evaluation of the Permian Park City Group in the northeastern Great Basin, Utah, Nevada, and Idaho, in Newman, G.W., and Goode, H.D., eds., Basin and Range symposium: Rocky Mountain Association of Geologists and Utah Geological Association, p. 523-530.

McKelvey, V.E., Swanson, R.W., and Sheldon, R.P., 1953, The Permian phosphorite deposits of western United States, in Saint Guilhem, M.R., ed., Origine des gisements de phosphates de chaux: Proceedings of the $19^{\text {th }}$ International Geological Congress, Algiers, 1952, sec. 11, no. 11, p. 45-64. [In French.]

McKelvey, V.E., Williams, J.S., Sheldon, R.P., Cressman, E.R., Cheney, T.M., and Swanson, R.W., 1959, The Phosphoria, Park City and Shedhorn Formations in the western phosphate field: U.S. Geological Survey Professional Paper 313-A, 47 p.

Reineck, H.-E., and Singh, I.B., 1975, Depositional sedimentary environments: Berlin, Germany, Springer-Verlag, $439 \mathrm{p}$.

Reineck, H.-E., and Singh, I.B., 1980, Depositional sedimentary environments (2nd ed.): Berlin, Germany, SpringerVerlag, 551 p.

Richards, P.W., and Mansfield, G.R., 1912, The Bannock overthrust-A major fault in southeastern Idaho and northeastern Utah: Journal of Geology, v. 20, no. 8, p. 681-709.

Sheldon, R.P., 1963, Physical stratigraphy and mineral resources of Permian rocks in western Wyoming: U.S. Geological Survey Professional Paper 313-B, p. 49-273.
Slansky, Maurice, 1979, Proposals for nomenclature and classification of sedimentary phosphate rocks, in Cook, P.J., and Shergold, J.H., eds., Proterozoic-Cambrian phosphorites: Canberra, Australia, Australian National University Press, p. 60-63.

Slansky, Maurice, 1986, Geology of sedimentary phosphates: New York, N.Y., Elsevier Science Publishing Company, $210 \mathrm{p}$.

Trappe, Jorg, 2001, A nomenclature system for granular phosphate rocks according to depositional texture: Sedimentary Geology, 145, p. 135-150.

Tucker, M.E., 1981, Sedimentary petrology-An introduction: New York, N.Y., John Wiley and Sons, 252 p.

Tysdal, R.G., Desborough, G.A., Herring, J.R., Grauch, R.I., and Stillings, L.A., 2000a, Stratigraphic sections and equivalent uranium (eU), Meade Peak Phosphatic Member of Permian Phosphoria Formation, Dry Valley, Caribou County, Idaho: U.S. Geological Survey Open-File Report 99-20-B, 1 sheet.

Tysdal, R.G., Grauch, R.I., Desborough, G.A., and Herring, J.R., 2000b, Stratigraphic sections and equivalent uranium (eU), Meade Peak Phosphatic Shale Member of Permian Phosphoria Formation, east-central part of Rasmussen Ridge, Caribou County, Idaho: U.S. Geological Survey Open-File Report 99-20-C, 1 sheet.

Tysdal, R.G., Herring, J.R., Grauch, R.I., Desborough, G.A., and Johnson, E.A., 2000c, Stratigraphic sections and equivalent uranium (eU), Meade Peak Phosphatic Shale Member of Permian Phosphoria Formation, Sage Creek area of Webster Range, Caribou County, Idaho: U.S. Geological Survey Open-File Report 99-20-D, 1 sheet.

Tysdal, R.G., Johnson, E.A., Herring, J.R., and Desborough, G.A., 1999, Stratigraphic sections and equivalent uranium (eU), Meade Peak Phosphatic Shale Member of Permian Phosphoria Formation, central part of Rasmussen Ridge, Caribou County, Idaho: U.S. Geological Survey Open-File Report 99-20-A, 1 sheet.

Wardlaw, B.R., 1995, Permian conodonts, in Scholle, P.A., Peryt, T.M., and Ulmer-Scholle, D.S., eds., The Permian of northern Pangea, Volume 1, Paleogeography, paleoclimates, stratigraphy: Berlin, Germany, Springer-Verlag, p. 186-195.

Wardlaw, B.R., and Collinson, J.W., 1986, Paleontology and deposition of the Phosphoria Formation: University of Wyoming Contributions to Geology, v. 24, p. 107-142.

Wentworth, C.K., 1922, A scale of grade and class terms for clastic sediments: Journal of Geology, v. 30, no. 5, p. 377-392.

Yochelson, E.L., 1968, Biostratigraphy of the Phosphoria, Park City, and Shedhorn Formations: U.S. Geological Survey Professional Paper 313-D, p. 571-660. 
